\title{
Az eltitkolt gáztámadás az olasz fronton az I. világháborúban
}

\section{ELŐZMÉNY}

1915. április 22-én először alkalmaztak tömegpusztító fegyvert - klórgázt - Belgiumban, Ypernél. A háború kedvezőtlen alakulása kényszerítette a német vezérkart az új fegyver bevetésére a franciák ellen. 170 tonna klórgázzal megtöltött, összesen 5730 tartályt telepítettek a 6,4 kilométer hosszú front mentén. A telepítésben részt vevő katonákat oxigénpalackokkal látták el, akik pedig ott is maradtak harcolni, egy speciális, a klórt megkötő nedves párnát kaptak. A cseppfolyósított harci gázt Fritz Haber német kémikus fejlesztette ki.

A klórgáz nehezebb a levegőnél, ezért völgy felé kell fújni. A gáztámadás 6 hetes előkészítést igényelt a nem megfelelő széljárás miatt. Ha visszafelé fúj a szél, akkor a saját erőket éri, ha pedig túl erős, akkor messzire viszi a gázt. A németek az ellenfél állásait elfoglalták, de nem nyo-

\section{1. ábra. A csapatok elhelyezkedése Segeti körül}

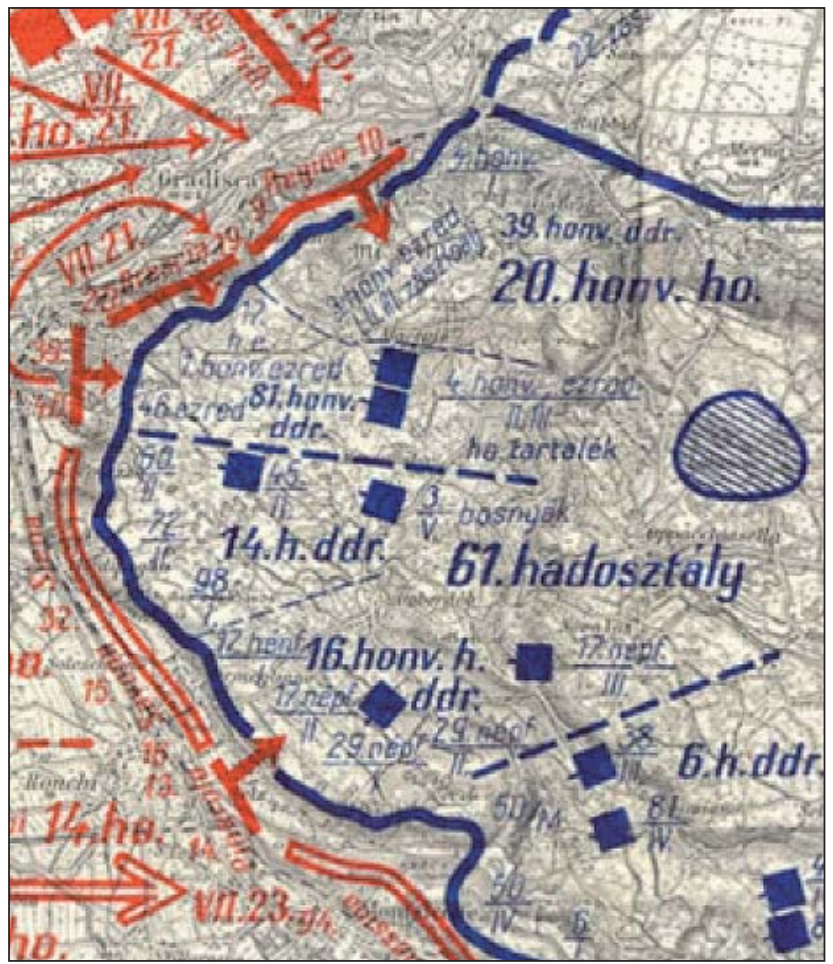

ÖSSZEFOGLALÁS: A közös hadsereg úgynevezett gáz- és lángszórós zászlóaljaiban szolgáltak magyar honvédek is. A magyarok bevetették a klórgázt az olaszok ellen. A támadást az I. honvéd gyalogezred III. zászlóalja hajtotta végre. Az ezred az Isonzó mentén Görz, Podgora, Monte San Michele térségében harcolt. multak tovább, a kedvező alkalmat nem használták ki a mélységbe történő előretörésre. Maguk is a bekövetkezett esemény hatása alatt álltak. A németek korábban aláírták a hágai egyezményt, ami megtiltotta a gázok használatát, de annyira vesztésre álltak, hogy megszegték a rendelkezést. A franciák egyik tábornoka észlelte a veszélyt, de nem hittek neki, így az antant hatalmai nem készültek fel a támadásra. A gáztámadásra vonatkozó parancsot április 22-én, 17 óra 30 perckor adták ki (sokadszorra, mert korábban nagy szelek fújtak). Hat-nyolc

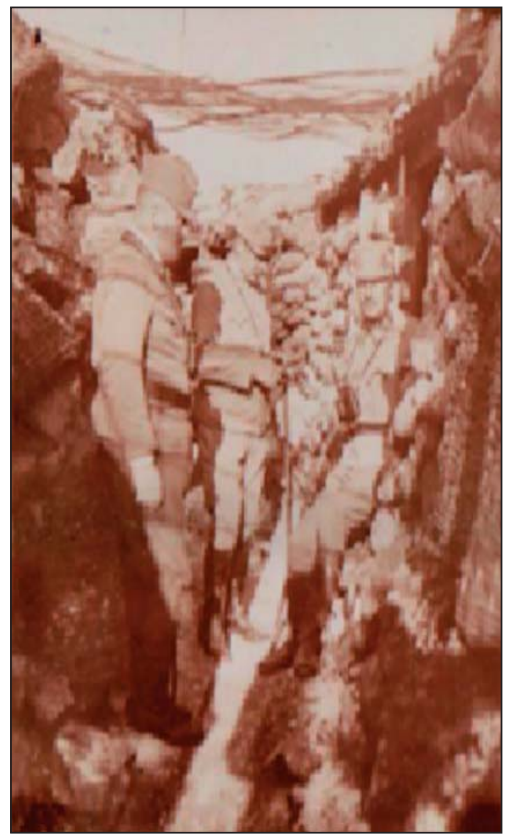

2. ábra. A vezérkar a frontvonalban: József föherceg, Putnoki Putnoky István örnagy az I. honvéd gyalogezred III. zászlóaljának parancsnoka, Lukasich tábornok

\section{3. ábra. Szélmérés}

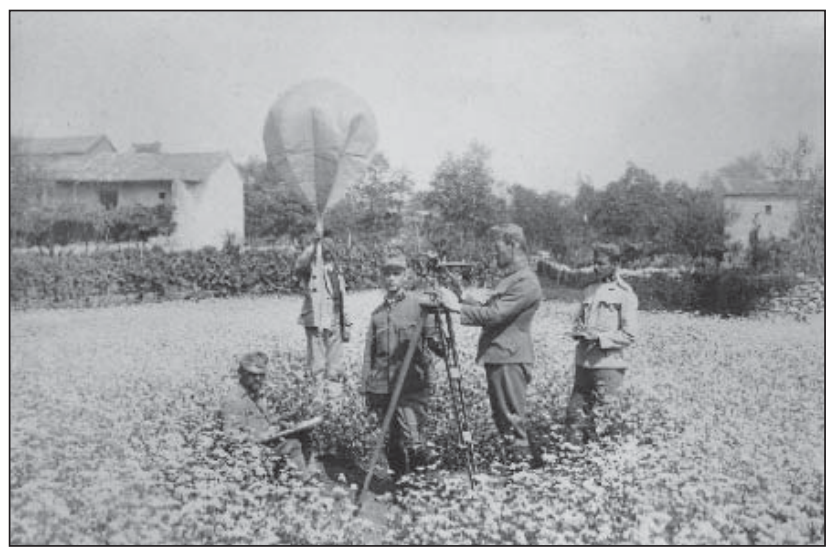

ABSTRACT: Hungarian soldiers also served in the so-called gas and flamethrower battalions of the Common Army. The Hungarian troops used chlorine gas against the Italian soldiers. The attack was executed by the 3rd Battalion of the 1st Infantry Regiment of the Royal Hungarian Army. The regiment fought along the river Isonzo, in the area around Görz, Podgora and Monte Ann Michele.

KEY WORDS: World War I, gas warfare, Austro-Hungarian Empire 


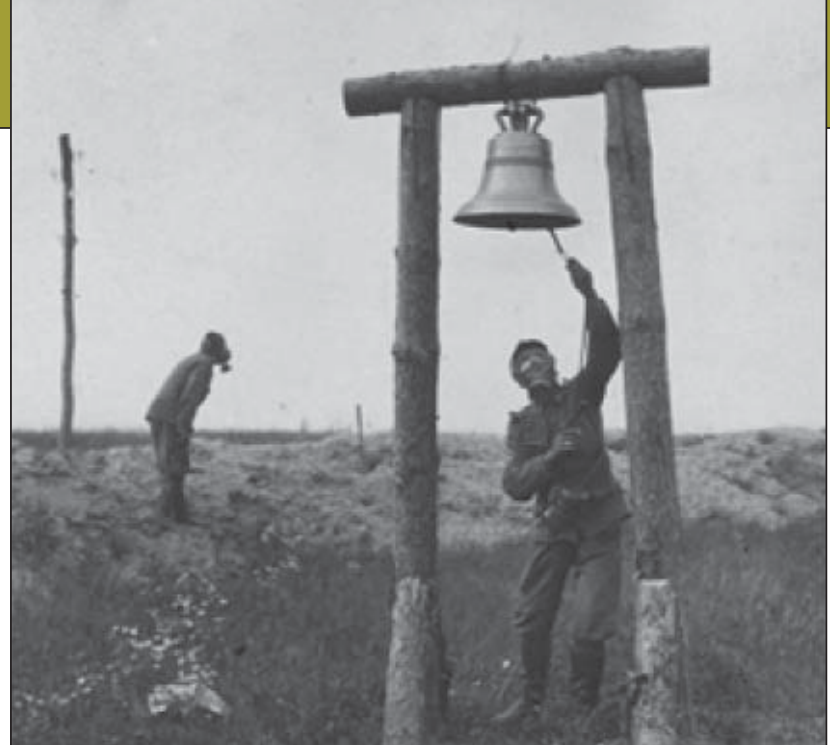

4. ábra. Eljött a gázriadó napja

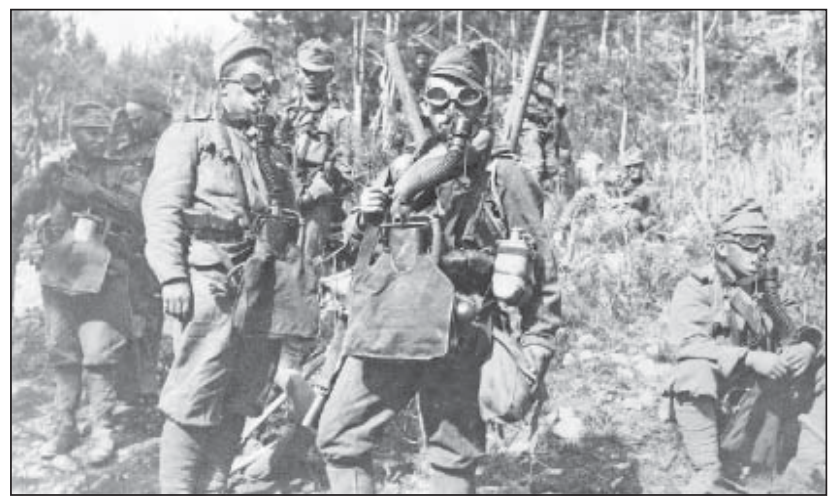

5. ábra. Gáztámadás előtt. Volt némi német felszerelésük, gázmaszk és sürített levegő

percbe tellett, míg kifúvatták a gázt (ennek éles hangja volt). Hatalmas felhő keletkezett. Az ellenség katonái heves torokfájdalmakkal, fülzúgással, fejfájással menekültek, többen vért köptek, vízért kiáltottak, a földön vonaglottak, rettenetes kínokat éltek át [1].

A Magyar Királyi Honvédségnek nem voltak ilyen csapatai, de a közös hadsereg úgynevezett gáz- és lángszórós zászlóaljaiban szolgáltak magyar honvédek is.

\section{A SEGETI TÁBOR}

A sorozatos isonzói csaták során az egyik fél sem ért el átütő sikert. Elkezdődött a felkészülés egy döntő ütközetre. 1915 nyarán a hadvezetőségnek gondoskodnia kellett az új

\section{6. ábra. Gáztámadás 1916. június 29-én}

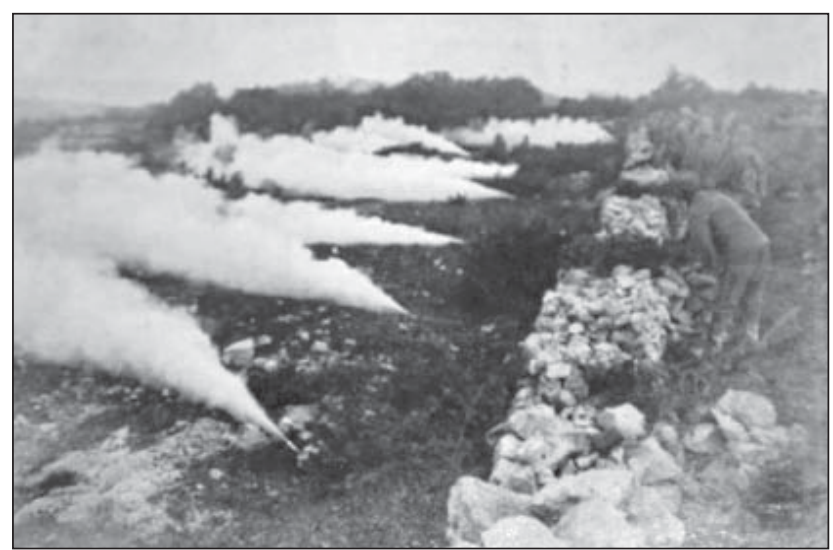

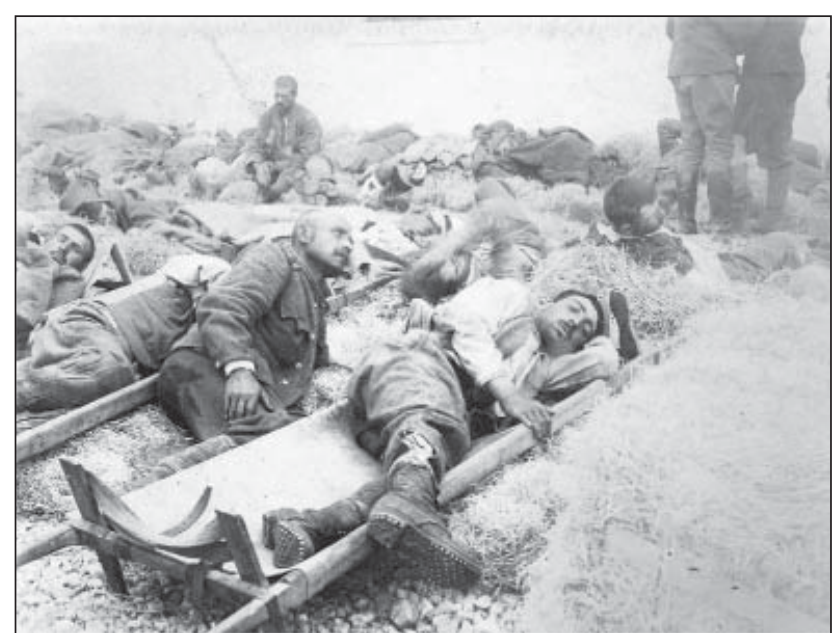

7. ábra. A gáztámadás olasz sebesültjei

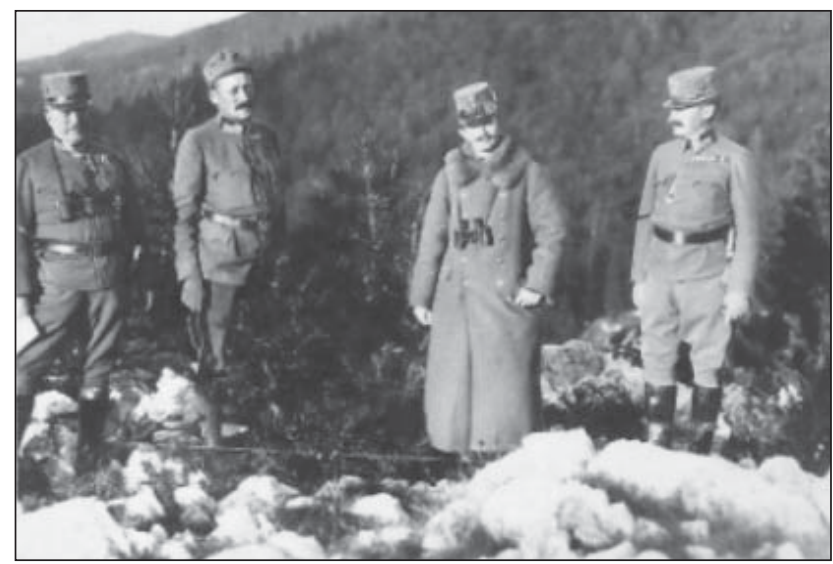

8. ábra. Őfelsége IV. Károly király és kísérete

hadszíntérre érkező nagyszámú katonatömeg megfelelő szállításáról, mozgásáról, elhelyezéséről, különböző testi és lelki szükségleteinek kielégítéséről is, hogy az hadra fogható legyen és az első vonalakban megfelelően helyt tudjon állni.

A tábor helyét az Isonzó patkó alakú vonalában, a doberdói fennsík frontvonal mögötti részén jelölték ki. [2]

A táborhely inkább egy kisvárosra hasonlított városrészekkel, az egyes alakulatoknak (debreceni, fehérvári, sze-

9. ábra. A templomok addigra már szét voltak lőve, vagy kórházként szolgáltak

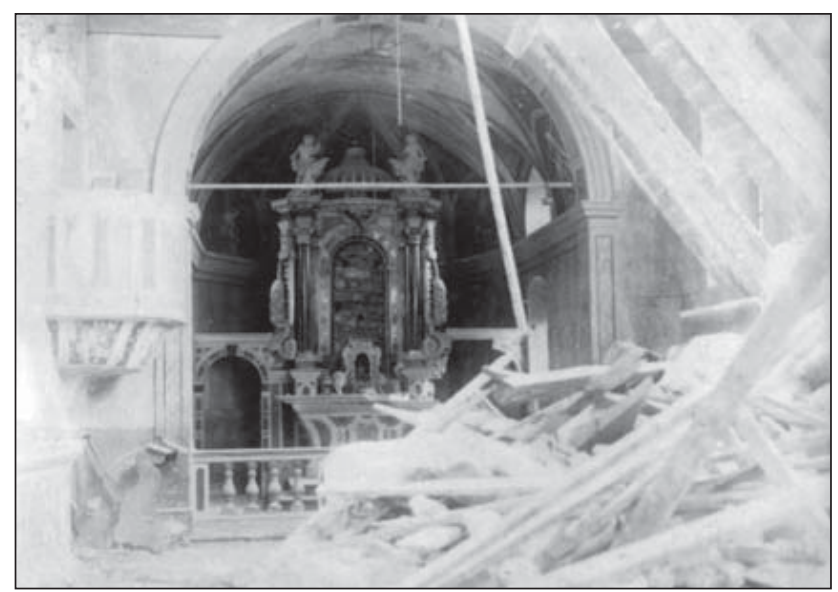




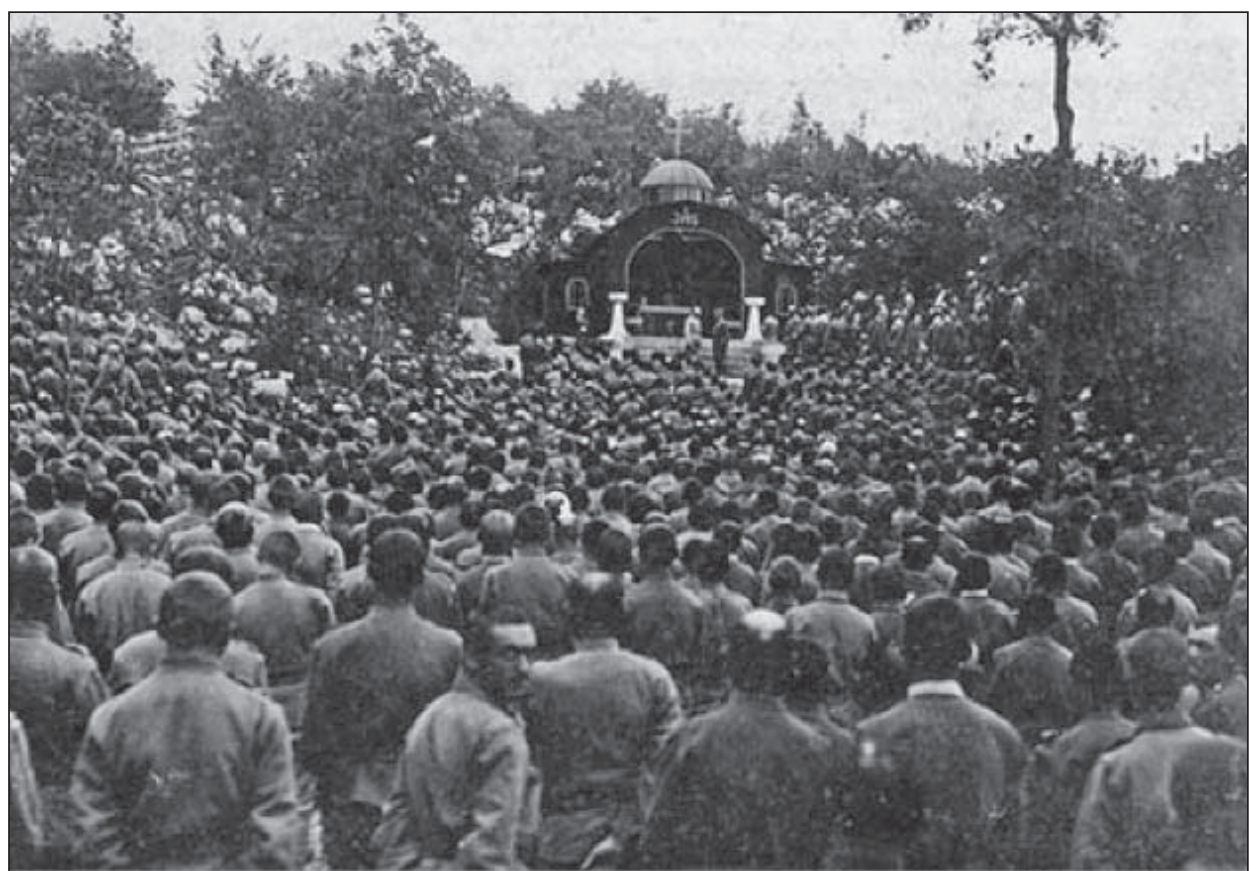

10. ábra. Tábori mise Segetiben

gedi, aradi) épült utcákkal, kőből készült barakkokkal. Az utcákat otthoni helyekről nevezték el. Mindenkinek megvolt a saját ágya. A táborban volt kórház és segélyhelyek, vasútállomás, fürdő, vurstli, sportolási lehetőségek, mozi és négy kápolna. A katonák tíz nap lövészárokharc után tíz nap pihenőt kaptak. Az volt az elv, hogy akkor szórakozzanak, addig nincs honvágyuk.

\section{GÁZTÁMADÁS}

A magyarok is bevetették a klórgázt az olaszok ellen, de csak jóval kisebb volumenben. Ez a tény nem szerepel a „nagy háború” dokumentumaiban. A hadtörténészeink se tudtak róla, amíg az archív képeket nem mutattam meg nekik, nem hoztam elérhetővé az érdeklődők számára. [3]

Egy fotóalbum nem írott történelem, csak a képek egymásutánjából lehet következtetni arra, hogy hol történhetett, kik hajtották végre és milyen következményekkel járt. Annyi azért kiderül a képekből, hogy a támadást az I. honvéd gyalogezred III. zászlóalja hajtotta végre. Az ezred az Isonzó mentén Görz, Podgora, Monte San Michele térsé-

\section{1. ábra. A köszönő sorokat Klotild föhercegnő tüzte be az} albumba

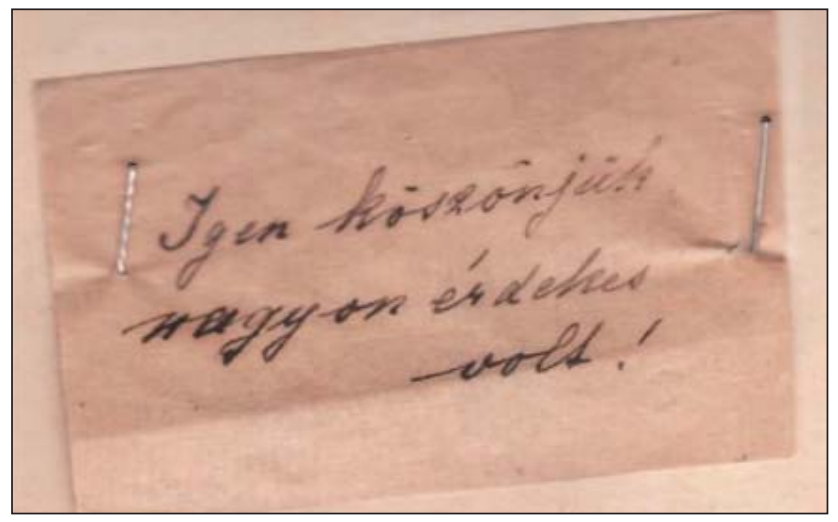
megsemmisült). letapad, vagy felszáll. jén bekövetkezett. ri fényképész felvételei alapján.)

\section{ForRÁSOK} Fórum 2000/4. gében harcolt. Nagyon sok olasz hadifogoly volt. Az ütközetben foglyul ejtett taljánoknak előre gyűitőhelyeket, segélyhelyeket hoztak létre és halottakra is felkészültek. A magyaroknak is volt segélyhely a „putnoki dolinában”.

Aznap véres ütközet volt. A hadba indulókról csoportképek készültek. Ezekhez később odakerült zárójelben a megjegyzés, mint „Váradi szakasz" (teljesen

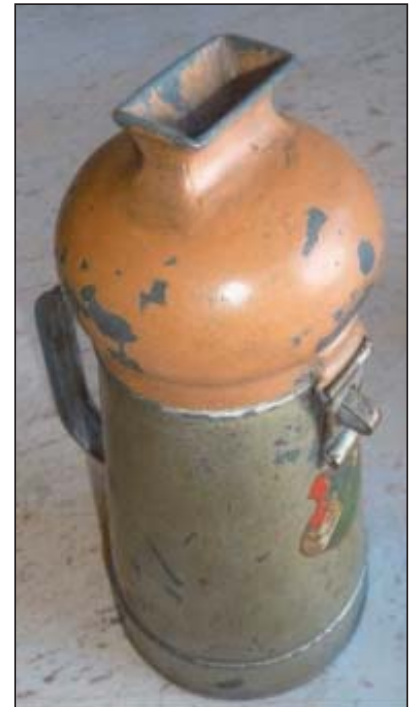

12. ábra. A segeti tábort a háború után nyomtalanul eltüntették, de a tábori kápolnából megmaradt egy tárgyi emlék: a tábori lelkész perselye

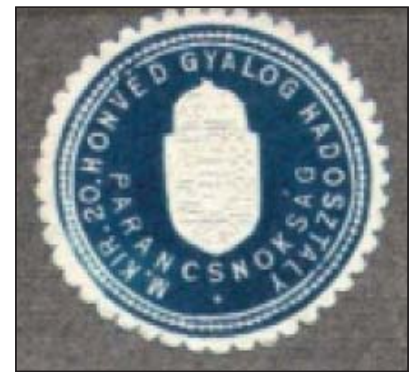

13. ábra. A magyar királyi honvéd 20. gyaloghadosztály parancsnokságának körpecsétje

A szélmérés, vagyis a terjedés meghatározás, azóta a vegyivédelem feladatkörét képezi. A szélirány és -sebességmérésen túl a levegőstabilitás (függőleges légmozgás) meghatározása a legfontosabb, mert attól függ, hogy a gáz

Akkor már visszavonhatatlanul közeledett a következő 6. isonzói ütközet időpontja, a doberdói, ami augusztus ele-

A doberdói vérfürdő nem hozott változást a fronton, mert az olaszok nem tudták elfoglalni a Trieszt felé vezető utat. Az 1917-es albumból kiderül, hogy a harcok ugyanazon a frontvonalon folytatódtak (7-9. ábra Isonzói csata) és az egyik fél sem ért el átütő sikert. (Bäumler Ede olasz harcté-

[1] Grósz Zoltán A vegyifegyver első bevetése, ZMNE

[2] Pintér Tamás Élet a doberdói frontvonal mögött - a Segeti tábor. előadás és cikk 2015;

[3] Bäumler Ede Olasz harctéri fényképfelvételek. Családi fotóalbum-gyűjtemény 1916-ban készült felvételeiből. 